\title{
THE IMPACT OF AGROCHEMICAL LOADING ON NUTRITIVE REGIME OF GRAY FOREST SOIL DURING FIELD CROP ROTATION
}

\author{
Olena Litvinova ${ }^{1}$, Stanislav Dehodiuk $^{2}$, Dmytro Litvinov ${ }^{1^{*}}$, Lyudmyla Symochko $^{3}$, \\ Yaroslava Zhukova ${ }^{4}$, Anzhela Kyrylchuk ${ }^{4}$ \\ ${ }^{1 *}$ National University of life and environmental sciences of Ukraine, Ukraine; \\ ${ }^{2} N S C$ «Institute of Agriculture NAAS, Ukraine; \\ ${ }^{3}$ Uzhhorod National University, Uzhhorod, Ukraine; \\ ${ }^{4}$ State Institution «Soils Protection Institute of Ukraine», Ukraine;
}

*Corresponding Author Dmytro Litvinov, e-mail: litvinovdv2018@ukr.net;

Received July 2021; Accepted August 2021; Published September 2021;

DOI: https://doi.org/10.31407/ijees11.421

\begin{abstract}
This paper presents the results of studies on how mineral and organic fertilizers influence agrochemical indicators of gray forest coarse light loam soil. It was found that when applying the organo-mineral fertilizer systems $\left(\mathrm{N}_{60} \mathrm{P}_{60} \mathrm{~K}_{68}\right.$ with 12 tons of manure per 1 ha of arable land) there was a tendency of increase of humus reserves to 35,1 t/ha per one treatment against the control of $28,1 \mathrm{t} / \mathrm{ha}$. The application of $12 \mathrm{t} / \mathrm{ha}$ of manure in crop rotation under the organic fertilizer system contributed to the most intensive accumulation of humus reserves in the tilth top soil $(0-20 \mathrm{~cm})-$ $36,5 \mathrm{t} / \mathrm{ha}$, with the soil solution acidity $\mathrm{pH}=5,2$. Over a five-year period, the average amount of hydrolyzable nitrogen in the experiment increased by 17-50\%, mobile phosphorus compounds rose by $50-75 \%$, mobile potassium compounds increased by $27-50 \%$ compared with the control of 44,1, 150 and $90,8 \mathrm{mg} / \mathrm{kg}$ of soil respectively. The highest level of fertility was provided by the application of $\mathrm{N}_{60} \mathrm{P}_{60} \mathrm{~K}_{68}$ with 12 tons of manure per 1 ha of crop rotation area, while the movement of nutrients took place within the root layer with no significant migration processes observed.
\end{abstract}

Key words: humus content, nitrogen, phosphorus, potassium, soil fertility, fertilizer system. 